\title{
Elevers berättelser om meningsfullt skrivande i skolan
}

\author{
Magnus Jansson, ^ Anja Thorsten och Håkan Löfgren \\ Linköpings universitet
}

\section{Sammanfattning}

Den här studien handlar om elevers erfarenheter av meningsfullt skrivande i skolan. Studien bygger på narrativa analyser av elevers muntliga berättelser om skrivande och literacyhändelser kopplade till skrivande. Studiens data består av intervjuer med nio elever i årskurs 6 . Som teoretisk utgångspunkt används New Literacy Studies med fokus mot skrivande som social aktivitet situerad i kontext. I berättelserna framträder skrivandet som meningsfullt när eleverna positionerar sig själva som skribenter och sina klasskamrater som olika typer av mottagare till deras texter. Positioneringarna handlar enligt elevernas utsagor om att framstå som en unik elev, lära andra något, övertyga andra eller skriva för att bli granskad av klasskamrater och lärare. Det framstår som viktigt att skrivandet kopplas till andra literacyhändelser, att texten presenteras för klasskamrater och lärare och att eleverna ges agentskap genom att få bestämma över textens innehåll och form.

Nyckelord: skrivande; meningsfullt; motivation; positionering; socialt sammanhang; kombination av literacyhändelser; elevers agentskap

\begin{abstract}
Students' experiences of meaningful writing in school

This study examines students' experiences of meaningful writing in school. The study is based on narrative analysis of students' oral stories about writing and literacy events in close connection to writing. The data consists of interviews with nine students in grade 6. The New Literacy Studies theory, which highlights writing as a social activity situated in context, is used as a theoretical starting point. In the students' stories, writing appears as meaningful when the students position themselves as writers and their classmates as different kinds of audiences. According to the students' utterances, the aim of the positioning is either to appear as a unique student, to teach others something, to convince others, or to be reviewed by classmates and teachers. Furthermore, it appears to be of importance to link writing to other literacy events, to present the text to classmates and teachers and to give students' agency, i.e., an opportunity to decide on the content and form of the text.
\end{abstract}

Keywords: writing; meaningful; motivation; positioning; social context; combination of literacy events; students' agency

Responsible editor: Gustaf B. U. Skar

Received: July, 2020; Accepted: September, 2021; Published: December, 2021

\footnotetext{
^Korrespondens: Magnus Jansson, e-post: magnus.k.jansson@liu.se

(C) 2021 Magnus Jansson, Anja Thorsten \& Håkan Löfgren. This is an Open Access article distributed under the terms of the Creative Commons Attribution 4.0 International License (https://creativecommons.org/licenses/BY/4.0/), allowing third parties to copy and redistribute the material in any medium or format and to remix, transform, and build upon the material for any purpose, even commercially, provided the original work is properly cited and states its license. Citation: M. Fansson, A. Thorsten $\mathcal{E}$ H. Löfgren. "Elevers berättelser om meningsfullt skrivande $i$ skolan" Nordic fournal of Literacy Research, Vol. 7(2), 2021, pp. 57-76. http://dx.doi.org/10.23865/njlr.v7.2511
} 


\section{Inledning}

Den här studien handlar om elevers erfarenheter av meningsfullt skrivande i skolan. Studien riktas mot vad elever berättar om sina erfarenheter och fokuserar meningsfullt skrivande utifrån ett elevperspektiv. En central utgångspunkt är att det skrivande som lärare och andra aktörer betraktar som meningsfullt för elever inte nödvändigtvis betraktas som meningsfullt av elever. Vårt fokus riktas därför mot skrivuppgifter som eleverna själva beskriver som engagerande och motiverande, till exempel skrivuppgifter som de beskriver som roliga, intressanta eller viktiga för dem. En annan central utgångspunkt är att elevers erfarenheter och inställning till skrivande är av betydelse för hur de tar sig an skrivuppgifter (Barton, 2007) och för deras prestationer i skolan (Graham et al., 2007; Hidi \& Boscolo, 2006, 2007; Liberg \& Säljö, 2020). Tidigare forskning visar att elever som upplever skrivande som en meningsfull aktivitet och är motiverade att skriva lyckas bättre än andra (Hidi \& Boscolo, 2006, 2007: Renniger et al., 2002). Flera forskare (Hall, 2013; Langer, 2004; Liberg \& Säljö, 2020; Smidt, 2011) menar också att det är viktigt att elevers skrivande riktas mot olika syften och att skrivandet sker och används i funktionella sammanhang. Deras forskning riktas dock inte mot vad elever själva upplever som funktionellt eller meningsfullt för dem, vilket den här studien handlar om. Det innebär att eleverna i den här studien betraktas som självständiga agenter, vilket enligt Bandura (2001) innebär att eleverna har intentioner och medvetna syften bakom sina handlingar, och att det eleverna berättar kan bidra med deras perspektiv på funktionellt och meningsfullt skrivande. I studier från Norden har det framkommit att elever inte alltid förstår vad eller varför de skriver (af Geijerstam, 2006; Malmbjer, 2012) och att lärares och elevers syfte med skrivandet inte alltid stämmer överens (Nilsson, 2002).

Flera forskare (Hidi \& Boscolo, 2006, 2007; Troia et al., 2012) menar att det behövs mer forskning om meningsfullt skrivande och elevers motivation för skrivande. Troia et al. (2012) efterlyser bland annat kvalitativt inriktad forskning med fokus mot förhållandet mellan elevers motivation och olika skrivuppgifter i skolan. För att kunna beskriva elevers erfarenheter av meningsfullt skrivande menar vi att det är viktigt att lyssna på vad elever säger om sitt skrivande. Vi använder därför en narrativ metod vilket innebär att vi studerar elevers erfarenheter och uppfattningar av meningsfullt skrivande så som de framstår när elever berättar om dem (Kohler Riessman, 2008). Det innebär att intresset bland annat riktas mot de positioneringar eleverna gör när de berättar om sitt skrivande och de sammanhang skrivandet är situerat i. Syftet med studien är att bidra med kunskap om vad som är av betydelse för att elever ska uppleva skrivande som en meningsfull aktivitet och med utgångspunkt från detta bidra till en diskussion om skolans skrivundervisning. Studien avgränsas till elever i årskurs 6. Denna avgränsning görs dels för att elever i årskurs 6 har några års erfarenhet av skrivande i skolan, dels för att de i årskurs 6 förväntas kunna "skriva olika slags texter med begripligt innehåll och i huvudsak fungerande struktur" (Skolverket, 2019, opaginerat). 


\section{New Literacy Studies}

Teoretiskt bygger studien på New Literacy Studies. Centralt i detta perspektiv är att skrivande ses som en social aktivitet förankrad i kontext (Barton, 2007; Street, 1984). Skrivande ses inte som en kognitiv färdighet som sker fristående från ett sammanhang utan istället som en aktivitet förankrad i de förväntningar, krav och värderingar som finns inom olika sociala praktiker (Street, 1984). Olika erfarenheter av skrivande medför därför att skribenter skapar mening med skrivande på olika sätt. För att betona kontextens betydelse för skrivande används inom New Literacy Studies begreppet literacies. Literacies handlar enligt Barton (2007, s. $37 \mathrm{ff}$ ) om att texter hanteras och skrivs på olika sätt beroende på syfte och sammanhang. Skrivande betraktas alltså inom New Literacy Studies inte endast handla om form och innehåll utan också om syfte och funktion.

Då vi betraktar skrivande som förankrat i kontext riktar vi inte endast fokus mot själva skrivandet utan också mot andra literacyhändelser som på något sätt framstår vara av betydelse för meningsfullt skrivande. Literacyhändelse är ett centralt begrepp inom New Literacy Studies och motsvarar händelser som på något sätt står i relation till skrift (Barton, 2007, s. 37; Heath, 1983, s. 71). Förutom själva skrivandet kan det handla om händelser före, under och efter skrivandet (till exempel planera skrivandet, rätta stavfel eller diskutera texten med någon). Literacyhändelser sker alltid inom ramen för en bestämd literacypraktik vilken både påverkar och påverkas av de literacyhändelser som sker. Begreppet literacypraktik är också centralt inom New Literacy Studies och omfattar de övergripande föreställningar som finns om skrivande i olika sammanhang (Barton, 2007, s. 37; Scribner \& Cole, 1981, s. 234 ff). Dessa föreställningar kan bygga på formella dokument, såsom skolans läroplan, men också på mer informella uppfattningar om elevers skrivande i skolan. Literacypraktiker är inte helt enkla att studera (Barton, 2007, s. 47) men eftersom literacyhändelser alltid är förankrade i en bestämd literacypraktik säger elevernas berättelser om olika literacyhändelser också något om den aktuella skolans literacypraktik.

Studien avgränsas till att omfatta berättelser om literacyhändelser i skolan. Fokus riktas inte mot i förväg bestämda literacyhändelser utan istället mot de literacyhändelser som eleverna väljer att berätta om. Vi utgår ifrån att elever kan ha olika syften med sitt skrivande och att skrivande därför kan fylla olika funktioner och vara meningsfullt för dem på olika sätt även om de arbetar med en och samma skrivuppgift.

\section{Motivation för skrivande}

Meningsfullt skrivande är nära kopplat till motivation för skrivande (Hidi \& Boscolo, 2006, 2007, s. 9; Troia et al., 2012). I jämförelse med forskning om motivation respektive forskning om skrivande finns det relativt lite forskning om förhållandet mellan motivation och skrivande. Den forskning som finns riktas antingen mot kognitiva och individuella aspekter, det vill säga intresse, självtillit och självreglerande strategier, eller mot sociala aspekter, såsom den funktion och mening som skrivandet fyller 
i olika sammanhang. Enligt Hidis och Boscolos översikter (2006, 2007) visar tidigare forskning att var och en av dessa aspekter är av betydelse för elevers motivation för skrivande. I nedanstående avsnitt presenterar vi först forskning med fokus mot kognitiva och individuella aspekter och därefter forskning om skrivande i skolan, $i$ vilket bland annat studier om sociala aspekter i relation till motivation tas upp.

Forskning om elevers intresse för skrivande visar att både intresse för det aktuella ämnet och intresse för skrivande som aktivitet är av betydelse för motivation (Hidi \& Boscolo, 2006). Elevers motivation ökar om de får skriva om något som de tycker är intressant eller om de får skriva på ett intressant sätt. Renniger et al. (2002) visar att elever med starkt intresse för det aktuella ämnet skriver tydligare och längre texter än andra. Lipstein och Renniger (2007) finner att elever med intresse för skrivande som aktivitet strävar efter att skriva bra texter medan elever som är ointresserade av skrivande främst strävar efter att få uppgiften gjord. Intresse för ämnet och intresse för skrivandet är alltså både av betydelse för elevers motivation och för de sätt som de hanterar skrivandet på.

Självtillit handlar om människors uppfattning om sin egen förmåga i förhållande till något. Forskning om förhållandet mellan självtillit och skrivande visar att elevers självtillit både är av betydelse för deras kunskaper och för deras prestationer (Hidi \& Boscolo, 2006, 2007, s. 7). DeBrine Mascle (2013) menar att elever med hög självtillit till skrivande engagerar sig mer och strävar efter att skriva bra texter medan elever med låg självtillit undviker skrivuppgifter eller skriver så kort som möjligt. Bruning et al. (2013) finner att elevers självtillit vad gäller olika aspekter av skrivande varierar. Elever kan till exempel ha stark tillit till sin förmåga att hitta på idéer men låg tillit till sin förmåga vad gäller skrivkonventioner. De finner också att elever med stark tillit till idéutveckling och självreglerande strategier är mer positivt inställda till skrivande än andra. Troia et al. (2012) menar att självtillit till olika aspekter av skrivande inte endast är av betydelse för elevers motivation utan också för deras skrivprestationer. De visar att självtillit till kunskap om skrivkonventioner påverkar kvaliteten på elevers texter mer än självtillit vad gäller enskilda skrivuppgifter. Enligt Bandura (1997) bygger självtillit på engagemang, observation av andra, feedback samt känslomässigt tillstånd. För engagemang i skrivande är det enligt DeBrine Mascle (2013) viktigt med en stöttande miljö, att det finns andra mottagare än läraren och att skrivandet fyller ett värde och en funktion utöver bedömning. Det är också viktigt att skribenter tvingas anstränga sig och får lära sig hantera svårigheter.

Självreglering handlar om de kognitiva, metakognitiva och motivationsskapande strategier som elever använder för att utveckla kunskaper av olika slag (Hidi \& Boscolo, 2006). I förhållande till skrivande kan det handla om strategier som elever använder för att kontrollera sig själva (till exempel den tid en skrivuppgift får ta), sina handlingar (till exempel hur något ska formuleras) och den omgivande miljön (till exempel var skrivandet ska ske). Zimmerman och Kitsantas $(1999,2002)$ visar i flera studier att undervisning om självreglerande strategier förbättrar elevers skrivkunskaper, inställning till skrivande och självtillit. 
Flera studier visar att det finns ett komplext förhållande mellan intresse, självtillit och självreglerande strategier. Bruning et al. (2013) finner till exempel att elevers självtillit är av betydelse för självreglering medan Hidi et al. (2002) menar att ett högt intresse för skrivande kan leda till hög självtillit och vice versa. Graham och Harris (2000) finner att tillgång till självreglerande strategier är av betydelse för både intresse och självtillit. De olika aspekterna påverkar alltså varandra.

\section{Skrivande i skolan}

I forskning med fokus mot sociala aspekter av skrivande betraktas elevers motivation för skrivande som beroende av den funktion och mening som skrivandet fyller för dem i olika sammanhang. Enligt Hidi och Boscolo (2006, 2007, s. 9) visar denna forskning att elever upplever skrivande som meningsfullt om skrivandet används och sker i relation till andra aktiviteter i klassrummet. Det kan till exempel handla om att kommunicera tankar och känslor i skrift till andra eller om att använda skrivande som redskap för lärande i olika ämnen. Internationell forskning (Boscolo \& Carotti, 2003; Britton et al., 1975) visar dock att skrivandet i skolan främst sker isolerat från ett sammanhang och som ett ämne i sig. Skrivandet omfattar främst faktatexter med syfte att formulera och bearbeta information av olika slag och fyller därmed främst en snäv, avgränsad funktion. Flera studier från Norden visar ett liknande resultat. Studier från Norge (Smidt, 2007; Solheim et al., 2010), där fokus riktas mot skrivandet i några klasser under en längre period, visar att de flesta skrivuppgifter som eleverna arbetar med antingen riktas mot texters innehåll eller form. Skrivandet används alltså främst för att eleverna ska tillägna sig kunskaper i ett ämne eller lära sig skriva. Skrivuppgifter med fokus mot texters innehåll omfattar kortsvarstexter, fylleriuppgifter, refererat från läromedel, reflektioner om arbetet i skolan (Solheim et al., 2010) eller tankekartor och rapporter från experiment (Smidt, 2007). Skrivuppgifter som används för att elever ska lära sig skriva omfattar avgränsade delar av texter, såsom inledning eller avslutning (Smidt, 2007), eller olika texttyper, till exempel berättande texter eller beskrivande texter (Solheim et al., 2010).

En stor del av de skrivuppgifter som eleverna i Solheim et al. (2010) respektive Smidts (2007) studier arbetar med bygger på uppgifter i läromedel. Studier om skrivuppgifter i läromedel visar att en övervägande majoritet av dessa handlar om texters form (Magnusson, 2018; Westman, 2013). Flertalet skrivuppgifter riktas mot texters form på detaljnivå, såsom regler för stavning, skiljetecken och gemener kontra versaler (Westman, 2013) medan andra riktas mot texters form och struktur på en mer övergripande nivå (Magnusson, 2018). De handlar då om de språkliga drag som utmärker olika typer av texter eller genrer.

Nordisk forskning om skrivande visar också att syftet med skrivandet inte alltid är tydligt för elever (af Geijerstam, 2006; Malmbjer, 2012; Nilsson, 2002; Solheim et al., 2010), ibland inte heller för lärare (Malmbjer, 2012; Westman, 2009). af Geijerstam (2006), som studerar mellan- och högstadieelevers skrivande i NO, finner att elever 


\section{Fansson, A. Thorsten $\mathcal{E} H$. Löfgren}

inte alltid förstår vad, varför eller till vem de skriver. Nilsson (2002), som studerar högstadieelevers arbete med egen forskning, visar att elever och lärare inte alltid uppfattar syftet med skrivande på samma sätt. Lärares syfte med skrivuppgifter är att elever ska lära sig något om det ämne som de skriver om, medan många elever uppfattar att de skriver för att visa vad de lärt sig. De uppfattar alltså skrivandet som en examinerande uppgift. Ett liknande resultat finns i Malmbjers (2012) studie, vars fokus riktas mot skrivande på mellanstadiet. Hon finner att skrivandet utmärks av en "att-göra-kultur" vilket innebär att skrivandet främst är av instrumentell karaktär. Det handlar om att göra färdigt skrivuppgifter så snabbt som möjligt för att kunna fortsätta med nästa. Skrivandets funktion för elever i skolan framstår alltså inte endast som starkt avgränsad eller snäv (Hidi \& Boscolo, 2006) utan ibland också som otydlig.

Tidigare forskning visar alltså att en mängd olika aspekter är av betydelse för elevers motivation för skrivande. Vår studie avser bidra med ytterligare kunskap inom detta område genom att analysera elevers berättelser om sina erfarenheter av meningsfullt skrivande.

\section{Narrativ ansats}

För att kunna studera elevers erfarenheter av meningsfullt skrivande används i den här studien en narrativ ansats (jfr Kohler Riessman, 2008). Det innebär att vi studerar vad elever berättar om sina erfarenheter av skrivande i skolan och att vi i analysen fokuserar på hur dessa erfarenheter beskrivs som meningsfulla. Med erfarenheter avses dels händelser som eleverna varit med om, dels de sätt som eleverna förstår dessa händelser på (jfr Perez Prieto, 2006, s. 9-10). Berättelser betraktas inte som en direkt återspegling av erfarenheter, men inte heller som helt fristående från dem. I linje med Perez Prieto (2006, s. 11) betraktar vi berättelser som formade av de erfarenheter som de handlar om och av den mening som berättare tillskriver dem. Berättelser kan på så sätt både säga något om enskilda händelser och något om hur berättare tolkar, förstår och värderar händelser.

Berättelser berättas alltid inom ramen för ett socialt sammanhang. Berättelser betraktas därför i den här studien som sociala konstruktioner (Mishler, 1999, s. 19). Intervjuaren bidrar till berättelsen genom de frågor som ställs och de sätt som frågorna ställs på medan deltagare bidrar genom de svar som de ger. Både frågor och svar påverkas av de förgivettaganden som finns i den aktuella situationen och på föreställningar om vad som är meningsfullt för den eller dem som lyssnar (Kohler Riessman, 2008, s. 3).Vi tillskriver därför inte intervjuaren en objektiv funktion utan betraktar istället intervjuaren som medskapare till berättelserna.

Berättelser betraktas också i den här studien som meningsskapande aktiviteter. Deltagare förstår händelser och erfarenheter genom att berätta om dem (Kohler Riessman, 2008, s. 10) och deltagare och lyssnare förstår varandra genom det samspel som utvecklas (Mishler, 1999, s. 15). Händelser blir genom berättelser erfarenheter 
som deltagare och intervjuare kan förstå och tolka tillsammans. Enligt Kohler Riessman (2008, s. 5) utmärks berättelser ofta av en sekvenserad "storyline". Analyser av berättelser som formas i intervjudata riktas därför vanligen mot avsnitt där händelser och idéer av olika slag kopplas samman och bildar mönster som går att förstå som logiskt sammanlänkade. Det kan till exempel handla om avsnitt där människor förklarar varför de gjorde på det ena eller andra sättet i olika situationer (Perez Prieto, 2006, s. 10).

För att förstå vad eleverna berättar intresserar vi oss främst för innehållet i elevernas berättelser. Hur eleverna berättar kan dock säga något om vad de berättar. I analysen av berättelserna riktar vi därför främst fokus mot vad eleverna säger, men också ett visst fokus mot interaktionen mellan deltagarna i samtalet och vilka ord de använder för att beskriva eller förklara något.

En central utgångspunkt för den här studien är även att berättelser kan studeras genom positioneringsanalyser (Bamberg, 1997; Mishler, 1999, s. 16-17). Positioneringar kan studeras dels genom analyser av hur deltagare genom sitt berättande positionerar sig själva i förhållande till händelser och personer i berättelsen, dels genom studier av hur personer i berättelsen positioneras i förhållande till varandra (Bamberg, 1997). Positioneringsanalysen i den här studien riktas mot relationen mellan eleverna som berättar och den sociala omgivning de berättar om och används för att förstå vilken betydelse klasskamrater och lärare har för att elever ska uppleva sitt skrivande som meningsfullt.

\section{Data}

Eleverna som deltar i studien går i årskurs 6 i två olika klasser på en mellanstor skola i en mindre stad i södra Sverige. Inför studien informerades eleverna och deras målsmän om studien och förutsättningar för deltagande vad gäller syfte, frivillighet, konfidentialitet och nyttjande (Vetenskapsrådet, 2011). Av sammanlagt 43 elever i årskurs 6 gav nio medgivande till deltagande och samtliga nio intervjuades. Då narrativ forskning riktas mot det specifika och unika - till exempel specifika händelser, aktörer eller platser - menar vi att nio deltagare är tillräckligt. Enskilda berättelser kan bidra med detaljer som tillsammans med andra berättelser kan ge en mer fullständig bild av det fenomen som studeras (Kohler Riessman, 2008, s. 11). Att ta enskilda personers berättelser om sina erfarenheter på allvar och studera hur de tillskriver händelser mening kan på så sätt ge teoretiska bidrag till fenomen av olika slag (Kohler Riessman, 2008, s. 13).

Intervjuerna var semistrukturerade. Frågorna handlade om texter som eleverna skrivit, händelser i samband med skrivandet och om elevernas uppfattningar om skrivandet. Samtliga intervjuer började med frågan "har du skrivit någon text under den senaste tiden" och fortsatte sedan med frågor om vad texten handlade om, vad eleverna gjorde före, under och efter skrivandet samt vad de tyckte om skrivandet. Därefter ställdes frågor riktade mot intressant, roligt eller viktigt skrivande, till exempel "har du skrivit någon text som du tyckte var rolig att skriva". Vi ställde också frågor 


\section{Fansson, A. Thorsten $\mathcal{E} H$. Löfgren}

om motsatsen, det vill säga ointressant, tråkigt och onödigt skrivande.Vi ställde alltså både öppna frågor och mer riktade frågor för att ge eleverna möjlighet att berätta detaljerat om olika aspekter av skrivandet (jfr Kohler Riessman, 2008, s. 12).

Några elever ville helst bli intervjuade enskilt, andra tillsammans med en kamrat. För att göra det vi ansåg etiskt riktigt följde vi elevernas önskemål. Gruppintervjuer kan leda till att deltagare med gemensamma erfarenheter inte berättar allt utan tar en del för givet - men också till att de kommer ihåg händelser som de tidigare inte lagt någon vikt vid (Goodson \& Sikes, 2001). De elever som intervjuades i par berättade både på egen hand och tillsammans.

Intervjuerna genomfördes på skoltid i ett rum bredvid elevernas klassrum. Den kortaste är 33 minuter och den längsta 1 timme och 16 minuter.

Tabell 1. Intervjuernas längd

\begin{tabular}{lc}
\hline Deltagares fiktiva namn & Intervjuernas längd \\
\hline Erik & 47 minuter \\
Lisa och Stina & 1 timme 16 minuter \\
Melker & 34 minuter \\
Kajsa & 55 minuter \\
Alba & 33 minuter \\
Kalle och Albin & 55 minuter \\
Klara & 25 minuter \\
\hline
\end{tabular}

Samtliga intervjuer transkriberades i sin helhet. I forskning där berättelser ses som socialt konstruerade är det viktigt att både återge det samtalsdeltagarna säger och hur samspelet mellan deltagarna utvecklas (Mishler, 1999, s. 20). Upprepningar, oavslutade ord och andra uttryck transkriberades för att underlätta tolkningen av hur berättelserna kan förstås i sitt sammanhang. I resultatdelen har dock uttryck som "ee", "uhum" och liknande tagits bort för att öka läsbarheten. För att särskilt uppmärksamma hur berättelserna konstruerades återvände vi under analysen till de inspelade intervjuerna och lyssnade på dem.

\section{Analys}

Analysen genomfördes i flera steg. I det första steget lästes samtliga transkript för att finna avsnitt där skrivande på något sätt framstod som meningsfullt för eleverna. Mer konkret riktades fokus mot avsnitt där eleverna berättade om literacyhändelser där skrivandet framstod engagera och motivera dem, till exempel genom att vara roligt, intressant eller viktigt. I det andra steget studerades dessa avsnitt för att finna sekvenserade storylines, det vill säga avsnitt där olika literacyhändelser kopplades samman på sätt som visade varför eleverna upplevde skrivandet som meningsfullt. Fokus riktades med andra ord mot avsnitt där eleverna beskrev vad som var av betydelse för att de skulle uppleva skrivandet som engagerande eller motiverande på något sätt. 
Osammanhängande utsagor och avsnitt där det inte framgick vad som gjorde att eleverna upplevde skrivandet meningsfullt sållades i detta skede bort. I ett tredje steg jämfördes de berättelser som motsvarade sekvenserade storylines med varandra för att finna likheter och skillnader mellan dem. Detta ledde till att fyra berättelser valdes ut. Dessa motsvarar centrala skillnader mellan berättelser i datamaterialet.

I nästa steg studerades de berättelser som valts med utgångspunkt från hur eleverna positionerade sig i förhållande till de literacyhändelser som de berättade om och i förhållande till hur deltagarna positionerades i förhållande till varandra. Klasskamraters och lärares position som mottagare av elevernas textproduktion studerades särskilt noga för att förstå vilken betydelse det sociala sammanhanget tillskrevs av eleverna. Därefter jämfördes elevernas berättelser med tidigare forskning om motivation för skrivande. Avslutningsvis riktades fokus mot centrala poänger i varje enskild berättelse för att förstå meningsfullt skrivande i förhållande till den aktuella skolans literacypraktik.

De tre första stegen genomfördes av en av författarna, medan samtliga författare genomfört granskning och analys av de fyra valda berättelserna kontinuerligt under arbetets gång.

\section{Tillförlitlighet}

Eftersom studien bygger på ett begränsat antal intervjuer visar studiens resultat hur ett begränsat antal elever kan uppleva meningsfullt skrivande i skolan. Vi gör alltså inte anspråk på att beskriva alla elevers erfarenheter av meningsfullt skrivande i generella termer. De berättelser som vi presenterar ska inte heller ses som återgivningar av en sann verklighet utan istället som beskrivningar av meningsfullt skrivande så som det framstår när elever berättar om det. Det innebär att elevernas berättelser ska ses som påverkade av de händelser som de handlar om och den mening som eleverna tillskriver dem i den aktuella intervjusituationen (Perez Prieto, 2006, s. 11). Då den literacypraktik som eleverna berättar om är en del av skolans övergripande literacypraktik menar vi dock att det är möjligt att elever på andra skolor arbetar med liknande skrivuppgifter och att andra elever därmed också upplever meningsfullt skrivande på ett liknande sätt.

För att ge läsaren möjlighet att avgöra om studiens resultat går att överföra till andra liknande kontexter har vi angett vilken årskurs eleverna går $i$, hur många klasser som deltar och skolans läge. Vi beskriver också vilken typ av text elevernas berättelser handlar om, vilka frågor som ställdes vid intervjuerna och vad eleverna svarade. Dessutom presenterar vi både överordnade och underordnade aspekter av meningsfullt skrivande, elevernas förklaringar till varför olika aspekter är av betydelse samt hur överordnade och underordnade aspekter förhåller sig till varandra. Vi har med andra ord strävat efter att stärka studiens tillförlitlighet genom att ge rika och fylliga beskrivningar av de kontextuella förhållanden som studien är förankrad i och den dialog som utvecklats mellan intervjuaren och deltagarna (jfr Bryman, 2018, s. 468). 


\section{Resultat}

I detta avsnitt presenteras fyra olika berättelser om meningsfullt skrivande i skolan. De tre första berättas av elever som intervjuades enskilt, medan den sista berättas av två elever som intervjuades tillsammans. Berättelserna liknar varandra på flera olika sätt, men det finns också några viktiga skillnader mellan dem. Centralt i samtliga berättelser är att det meningsfulla skrivandet är nära kopplat till frågor om lärande vilket är naturligt då de hämtas från en skolkontext. Vidare betonas i berättelserna att själva skrivandet bara är en av flera literacyhändelser som sammantaget blir betydelsefulla i elevernas berättelser. Särskilt viktiga literacyhändelser i berättelserna handlar om förberedelser och redovisning av texter. Slutligen, och kanske viktigast, illustrerar berättelserna betydelsen av det sociala sammanhanget i vilket texterna produceras. I synnerhet handlar det om den position klasskamrater och lärare ges som mottagare av de texter som skrivs. Det som framförallt skiljer de olika berättelserna åt är hur de elever som berättar om sina skriverfarenheter tar olika meningsskapande positioner då de talar om sina förberedelser, redovisningar och om sin "publik". I det följande visar vi hur meningsfullt skrivande i berättelserna främst handlar om att skriva för att själv bli unik i andras ögon, om att lära andra något, om att kunna övertyga andra samt om att bli bedömd av andra.

\section{Att skriva för att bli unik}

Den första berättelsen berättas av Melker. Skrivande framstår i Melkers berättelse som meningsfullt om det ger honom möjlighet att särskilja sig från ett kollektiv och markera sin individualitet. Melkers klasskamrater positioneras i berättelsen som mottagare till texten och som elever som helst ska bli imponerade av hans unika val. Melker positioneras därmed genom berättelsen som en elev som med hjälp av kunskaper som ingen annan har vill framstå som unik.

Berättelsen handlar om två olika texter som Melker skrivit. Den ena texten handlar om ovanliga sjukdomar och den andra om regnbågar. Melker talar först om texten om ovanliga sjukdomar.

Intervjuaren: När du tänker på den nu när vi sitter och pratar om, hur känner du då, känner du dig glad eller känns det, å, jobbigt eller?

Melker: Ja det känns ju både roligt för att skriva en faktatext är väldigt kul för då lär man sig ju alltid nåt nytt. För jag brukar alltid ta nåt som jag inte vet så mycket om, eller, om jag vet nånting så tar jag, så letar jag upp det som jag in, som jag inte vet om den saken eller ja, så man lär sig alltid nåt nytt.

[...]

Intervjuaren: Vad kan göra att det blir ointressant och skriva?

Melker: $\quad$ Det är ju om de är nåt gammalt du kan och liksom om du inte hittar nåt nytt då blir det ju väldigt ointressant det finns ingen sida som liksom säger nånting annorlunda liksom du letar och sen lektion och inte hittar nånting då kan det kännas negativt och inte kul. 
Här framstår det som viktigt att Melker får skriva om ett ämne som han "inte vet så mycket om" eftersom det ger honom möjlighet att lära sig något nytt. Om han ska skriva om något "gammalt du kan" blir skrivandet ointressant och tråkigt. Valet av och sökandet efter - ett lämpligt ämne framstår därmed i den här berättelsen som en central literacyhändelse. När Melker berättar om regnsbågstexten förstärks detta:

Melker: Jag skrev en text om regnbågar nån gång, eller regnbåg, ja regnbågar, och då skulle jag hitta hur den bildades, hur den liksom, ja, vart den här historien kom med att det är en pyssling vid änden av regnbågen, lite sånt liksom, då var det svårt att hitta det liksom [...] det fanns inte på så många sidor, jag fick gå igenom nästan tio sidor innan jag hittade liksom, det som jag letade efter. [...]

Intervjuaren: Kommer du ihåg varför du valde den texten, eller den ...

Melker: Det var ju att jag, jag visste inte nånting om regnbågar typ, jag viss, ja liksom det är lite sånt jag visste ingenting om regnbågarna och lite sånt.

När intervjuaren frågar "var det just det här att de var svårt som, som gjorde att du valde det då eller?" framstår valet av ämne inte endast vara av betydelse för att Melker ska få möjlighet att lära sig något nytt. Istället framstår valet av ämne främst vara av betydelse för att han ska kunna framträda med något unikt och spännande inför sina klasskamrater:

Melker: $\quad$ Nej, det var väl mest att man, jag vill gärna va, jag vill alltid va den som är unik [...] och väljer nånting som ingen annan vill väljer liksom [...] så att jag kände att det var det och jag visste inte så mycket om det så liksom det här kör jag på liksom.

Intervjuaren: Hur kommer det sig att du vill välja sånt som ingen annan gör?

Melker: Det är väl att jag inte jag vill jag vill va själv om nånting och hitta fakta själv och läsa upp den själv och ingen annan ska läsa upp liksom läsa upp men nästan likadan text liksom jag vill va själv och göra det liksom.

Här framstår det som viktigt att ämnet inte endast är nytt för Melker utan också för hans klasskamrater. Ingen annan ska kunna något om ämnet. Anledningen till detta är att "jag vill alltid va den som är unik". Det handlar om att få "läsa upp den själv" och att ingen annan ska läsa upp en "nästan likadan text". Redovisningen av texten framstår därmed som en viktig literacyhändelse.

Melker framstår i berättelsen som en elev med hög tillit till sina skrivkunskaper. Han strävar efter att lära sig något nytt, utmana sig själv och tycks inte undvika ämnen som är jobbiga eller svåra. Han säger "jag väljer ju aldrig nånting direkt som jag liksom tycker är tråkigt. Jag kanske tycker det är jobbigt och svårt men jag väljer ju aldrig nånting jag tycker är tråkigt att läsa om." Melkers motivation förefaller drivas av möjligheten att utveckla kunskaper som ingen annan har.

Den aktuella skolans literacypraktik framstår i Melkers berättelse som en viktig arena för det sociala samspelet mellan elever och för elevers identitetsskapande. Genom berättelsen positionerar Melker sig som en elev som gillar att förbereda sig 
väl för att kunna framträda med något unikt inför klassen, vilket är det som gör skrivandet meningsfullt.

\section{Att skriva för att lära andra något}

Den andra berättelsen berättas av Erik. Berättelsen handlar om att det är viktigt att skriva en text som klasskamraterna tycker är intressant och som de kan lära sig något av. Genom berättelsen positionerar sig Erik som någon som är mån om att lära ut och göra sig förstådd.

Texten som Erik talar om är en argumenterande text om kärnkraft som han skrivit någon dag före intervjun. Han börjar dock med att tala om skrivande i allmänhet:

Erik: $\quad$ När man skriver en text, om man, då skriver man ju om det man liksom kan och det man tycker verkar intressant och det man tror de andra tycker är intressant. För om man, man kan ju liksom inte bara skriva av. Inte rätt, om man själv tycker det verkar jättetråkigt, inte alls kul, men så hittar man nånting som man tycker är kul så använder man sig av det.

I likhet med föregående berättelse framstår det som viktigt att ämnet är intressant. Det handlar om att hitta "nånting som man tycker är kul". Det räcker dock inte med att ämnet är intressant för Erik - ämnet ska också vara lärorikt för hans klasskamrater. När Erik berättar varför han valde att skriva om kärnkraft säger han:

Erik: $\quad$ Jag vet inte, alltså det var ju för att det var en väldigt stor grej, jag vet inte om många vet just att just kärnkraft var var, de har säkert hört talas om det, att man får värme och el, men de kanske inte liksom vet hur det går till, vad det finns för risker, om det blir kärnkraftsolycka. Man vet inte så mycket om det.

Här riktar Erik fokus mot klasskamraternas eventuella kunskapslucka, det vill säga deras brist på kunskaper om kärnkraftens risker. Det framstår som viktigt att skriva en text om något som klasskamraterna inte kan så mycket om och som klasskamraterna kan lära sig något av. Valet av - och sökandet efter - ett nytt ämne framstår alltså även i den här berättelsen som en viktig literacyhändelse. Till skillnad från den förra berättelsen står omsorgen om klasskamraternas lärande i centrum här, det viktiga är inte att Erik själv framstår som unik. Detta blir ännu tydligare när han fortsätter att tala om valet av ämne:

Erik: Jag tänkte att man var ju tvungen att göra så att dom andra tycker det är lite mer intressant, så att man liksom inte sitter och tycker, jag kanske tycker nånting som är jätteintressant men sen så läser jag upp det för en kompis och den tycker inte det är så intressant, då måste jag ju tänka, ja men jag kan ju säga om det jag tycker är intressant och dom andra så att inte bara, så att det inte bara blir min text alltså. Så att andra tycker det är kul att lyssna.

Här framstår det som viktigt att "göra så att dom andra tycker det är lite mer intressant" och skriva "så att det inte bara blir min text". För att fånga klasskamraternas 
intresse framstår det alltså inte endast som viktigt att skriva om ett intressant ämne utan också att skriva på ett intressant sätt. När intervjuaren frågar Erik hur han kände sig när han var klar med texten framstår det som viktigt att klasskamraterna förstår den:

Erik: $\quad$ Eee nej men alltså ... ja jag var nöjd med den liksom.

Intervjuaren: Ja. Vad var det som gjorde att du var nöjd med den då?

Erik: $\quad$ Ja $\mathrm{mm}$ det är just det där att intressant, sen när jag redovisade för kompisar, dom liksom förstod ... vad jag pratade om liksom [...]

I likhet med Melkers berättelse framstår redovisningen av texten som en central literacyhändelse. Men Eriks text om kärnkraft ska användas och fylla en lärande funktion i klassen snarare än som ett sätt att ställa honom själv i centrum. Eriks klasskamrater positioneras i berättelsen som en grupp som ska motiveras och lära sig något. Det är då skrivandet framstår som verkligt meningsfullt för honom.

Även Erik framstår som en elev med hög tillit till sina skrivkunskaper och till sin förmåga att förmedla ett innehåll till andra. Han framstår också som en noggrann elev som strävar efter att inta klasskamraternas perspektiv och anpassa sitt skrivande till dem. Eriks motivation att skriva tycks drivas av en önskan att förmedla en intressant text med ett intressant innehåll.

Den aktuella skolans literacypraktik framstår i den här berättelsen som en lärandepraktik där det är viktigt att elever motiveras att både lära ut och lära in. För att elever ska bli motiverade framstår det som viktigt att skolans literacypraktik ger dem utrymme att skriva om intressanta, nya och lärorika ämnen. Inte minst framstår det som viktigt att de även får hjälpa sina kamrater att lära sig något nytt.

\section{Att skriva för att övertyga andra}

Den tredje berättelsen berättas av Kajsa. I berättelsen positionerar hon sina klasskamrater som elever som ska övertygas om en viss ståndpunkt och sig själv som en elev som strävar efter att övertyga andra genom att skriva en text med en bestämd form och funktion. Det är på så vis skrivandet blir meningsfullt för henne. Det framstår även som viktigt att hennes tänkande utmanas och att hon får testa om texten fungerar som den ska.

Berättelsen handlar om en argumenterande text om cykelhjälmslagen som Kajsa skrivit någon dag före intervjun. När intervjuaren frågar vad eleven tyckte om att skriva texten svarar hon:

Kajsa: Det var roligt.

Intervjuaren: Vad var det som gjorde att du tycker att det var roligt tror du?

Kajsa: $\quad$ Att det var ju så här, man fick ju välja ifall man vill vara mot eller för, och då var det vissa som var mot, och sen så fick man ju liksom tänka efter ... jag vet inte ifall nån var mot cykelhjälmslagen, men i alla fall, och sen skulle man tänka efter motargument och sånt, och då blir det lite roligt så att man vill skriva en text som liksom övertygar om hur mycket typ, att det är mycket skador och sånt om 
dom som inte har cykelhjälm. Man skriver ju inte om, så här att cykelhjälm är dåligt i faktatexten, så man får ju tänka efter lite vad man skriver om och så. Det är lite roligt att man får liksom tänka efter lite.

Här framstår det som viktigt för Kajsa att skrivandet utmanar henne. Skrivandet är roligt om "man får liksom tänka efter lite". Tänkandet handlar om vad som ska tas med i texten och hur texten ska utformas, alltså om både innehåll och form. Tänkandet framstår som nödvändigt för att Kajsa ska kunna skriva en övertygande text. Skrivandet blir roligt för att "man vill skriva en text som liksom övertygar". I följande citat förstärks detta:
Kajsa:
Den var roligt för att man såg hela tiden fram emot att bli klar med texten, så att man skulle kunna få redovisa, så att man skulle få stå där och argumentera mot och för och så.
Intervjuaren: Så ni presenterade för ...
Kajsa: Ja, vi fick skriva stödord på lappar, och så från det så fick man ... ha en muntlig framföring, de stå för klassen, och så skulle dom komma på motargument för varför det inte va till exempel bra att ha cykelhjälm, typ att man förstör frisyren, och sen så skulle jag komma på liksom ett motargument medan jag står där. Om inte det som jag tänkt efter att dom redan skulle säga. $[\ldots]$
Intervjuaren: OK, så när du skrev så funderade du en del på att du skulle presentera det för klassen eller, var det nåt som du tänkte på sen efteråt?
Kajsa: $\quad$ Ja, det gjorde jag, för att lite så här att övertyga dom att det är bra att ha, i texten liksom, att det är bra att ha cykelhjälm.

Här framstår det som viktigt att texten redovisas på ett sätt som utmanar klasskamraterna att reagera och argumentera emot. Det handlar om att "få stå där och argumentera mot och för och så". I likhet med Melkers och Eriks berättelser framstår alltså redovisningen av texten som en literacyhändelse av central betydelse för meningsfullt skrivande. I detta fall handlar det dock om att väcka reaktioner och få motargument.

Kajsa framstår i berättelsen som en elev med hög tillit till sina skrivkunskaper. Hon räds inte redovisningen utan ser istället fram emot att få testa om texten fungerar. Kajsas motivation tycks drivas av att utforma en bestämd typ av text med en bestämd form och en bestämd funktion - att övertyga andra.

Den aktuella skolans literacypraktik framstår i den här berättelsen som en lärandepraktik där det är viktigt att elever får skriva texter som väcker engagemang och där eleverna får ta ställning och försvara sina ställningstaganden inför andra.

\section{Att skriva för att bli bedömd}

Den fjärde berättelsen berättas av Lisa och Stina. Skrivande framstår i den här berättelsen som meningsfullt om elevernas texter ska granskas av klasskamrater och lärare offentligt. Klasskamrater och lärare positioneras som bedömare och det framstår som viktigt att skriva en text som motsvarar klasskamraters och lärares krav. De båda 
eleverna positionerar sig som elever som förbereder sig på att leva upp till de krav som omgivningen ställer på dem och skrivandet får sin mening genom att det möjliggör för dem att bli godkända.

Berättelsen handlar om två argumenterande texter som eleverna skrivit en kort tid före intervjun. Berättelsen börjar med att intervjuaren frågar eleverna vad som kan göra skrivande viktigt.

Stina: $\quad$ Det är väl typ, jag tycker det känns viktigt att skriva argumenterande texter för att jag känner typ, ja men press på mig. När man ska ställa sig i den där halvmånen typ som alla sitter runt och så står man där och vet att nu kommer folk säga grejer, tänk om jag inte skrivit ner alla motargument som jag är beredd på att få till mig, vad ska jag säga då? Så att det känns som att man måste vara väldigt förberedd på en argumenterande text.

Skrivande framstår här som viktigt om texten ska redovisas. Stina förbereder sig på att stå i centrum för klassens uppmärksamhet, klasskamraterna ska framföra argument och hon vill kunna svara på dem. Redovisning av text framstår därmed även i den här berättelsen som en literacyhändelse av central betydelse för meningsfullt skrivande. För att kunna svara på klasskamraternas argument framstår det som viktigt att förbereda sig väl. Detta förstärks av den andra eleven:

Lisa:

$$
\begin{aligned}
& \text { Det är typ så här inför prov och sen argumenterande för då sätts man } \\
& \text { ju typ på prov. Bara, ”dom kommer säga massa saker till mig” [...] } \\
& \text { då känns det viktigt för att man, annars är man inte förberedd, då } \\
& \text { vet man inte vad man ska svara. Och bara, när man väl står där bara } \\
& \text { ”oj det där läste inte jag om, men jaja strunt i det”, då blir det liksom } \\
& \text { man är inte förberedd på samma sätt om man inte tar det på allvar } \\
& \text { typ när man läser och skriver om ... ja, som jag hade typ dödsstraff, } \\
& \text { då måste man kunna väldigt mycket för att, eller ha läst till sig väldigt } \\
& \text { mycket, för att kunna svara på alla argumenten. Så då känns det som } \\
& \text { pressen att inte stå där och bara, "jaha, jag vet inte vad jag ska svara } \\
& \text { på det där kan jag gå ner nu typ, jag går och sätter mig istället för jag } \\
& \text { kan inte svara på det här". }
\end{aligned}
$$

För att kunna hantera den press som eleverna utsätts för under redovisningen framstår det som viktigt att ta skrivandet på allvar, till exempel genom att lära sig mycket om ämnet och skriva många olika argument i texten. De förberedelser eleverna gör inför skrivandet, i form av läsande, framstår därmed som en central literacyhändelse. I följande citat framstår det också som viktigt att sätta sig in i mottagarnas perspektiv:

Stina: Det känns som att alla liksom bara bryr sig om argumenten jag har, så då i början brukar jag tänka "men om jag skriver det jag tror folk kommer säga så blir det nog bra" men sen vet ju inte jag hur andra tänker om liksom ... jag skriver om skoluniform då, och då vet ju jag liksom inte vad andra tycker om det och då blir det så här ”om jag inte tar med det här kommer, kommer jag liksom få så här massa argument på mig då eller vad ska jag svara"? 
För att kunna svara på klasskamraternas argument berättar Stina att hon försöker skriva "det hon tror folk kommer att säga". Trots att Stina försöker sätta sig in i klasskamraternas perspektiv framstår hennes kontroll över redovisningen som begränsad. Hon vet inte "hur andra tänker" och vet därför inte heller riktigt vad hon ska skriva. Stina framstår därmed som utelämnad till att gissa vad hon ska skriva och det förefaller finnas risk för att redovisningen misslyckas:

Stina: $\quad$ Ja. Det blir jättejobbigt om man står där så har man ögon på sig liksom så här "svara nu, du har väl argument mot det" liksom, så står man där och liksom så här, man ser att alla tittar på en, så blir det ... det blir väldigt nervöst om man inte kan svara. $[\ldots]$

Stina: $\quad$ Mm och sen så brukar ju [lärarens namn] sitta liksom bakom den här halvmånen och så sitter han där bakom och liksom "det här går på era betyg" så sitter han och skriver där så står man så här ... ja.

Intervjuaren: $\mathrm{OK}$

Lisa: Det blir som falkögon som alltid så här håller koll på en och bara, varenda litet fel ...

Stina: $\quad$ Skriver ner liksom, bara man eller vad vi gör bra eller vad vi inte gör bra och det går ju på betygen och då blir det så här. [...]

Lisa: $\quad$ Mmm och då blir man jättenervös och står där och börjar skaka och sen bara "ee" så blir så här skakig på rösten och sen, blir det inte lika bra för man har inte samma inlevelse typ när man är nervös, och då vill man bara få det överstökat och gå därifrån typ

Stina: $\quad$ Ja, så det är en lättnad när man går och sätter sig bara "jag gjorde det herregud".

Om eleverna inte kan svara på klasskamraternas argument blir de väldigt nervösa. Detta medför att risken för att misslyckas ökar.

Eleverna framstår i berättelsen som elever med låg tillit till sina skrivkunskaper. Trots att de använder flera olika strategier för att klara av redovisningen, som att lära sig mycket om ämnet och försöka sätta sig in i klasskamraternas perspektiv, framstår de som osäkra på om deras texter duger. Elevernas motivation tycks drivas av en vilja att prestera en text som hjälper dem att klara redovisningen med hedern i behåll.

Den aktuella skolans literacypraktik framstår i berättelsen som en bedömningspraktik där inte endast läraren utan också elevernas klasskamrater avgör om elevernas texter håller måttet - och där bedömningen av elevernas texter inte endast är av betydelse för deras betyg utan också för deras sociala position i klassen.

\section{Diskussion}

I den här studien intresserar vi oss för vad som enligt elevers berättelser gör skrivande i skolan meningsfullt för dem. I det följande diskuterar vi detta med utgångspunkt från tre aspekter som vi finner centrala: kopplingen mellan olika literacyhändelser, det sociala (sam)spelet mellan elever samt elevers agentskap. 
De texter som eleverna i den här studien väljer att berätta om när vi frågar om roligt, intressant eller viktigt skrivande är faktatexter. Faktatexter är en vanligt förekommande form av literacies i skolan som främst används för att elever ska lära sig något om ett ämne (jfr Smidt, 2007; Solheim et al., 2010). Gemensamt för olika typer av faktatexter är att de innehåller information om fenomen och företeelser av olika slag i världen. För att elever ska kunna skriva egna faktatexter behöver de därför tillägna sig kunskap om det fenomen eller den företeelse som de ska skriva om. Ett vanligt sätt för elever att skaffa sig denna kunskap, och som eleverna i den här studien också berättar om, är att läsa texter om ämnet. Literacyhändelser som föregår skrivande på detta sätt framstår i den här studien som nödvändiga för att skrivandet ska vara meningsfullt. Elevernas förberedelser och deras skrivande framstår dock inte som meningsfullt förrän de texter de skriver redovisas för andra. Det framstår alltså som viktigt att skrivandet används och fyller en funktion efter själva skrivandet (jfr Hidi \& Boscolo, 2006, 2007). Även om meningsfullheten skapas som en konsekvens av mötet mellan den redovisande eleven och mottagarna till elevernas texter är det först när serier av specifika literacyhändelser kopplas samman och bildar storylines som de framstår som meningsfulla för elever. Flera studier (af Geijerstam, 2006; Nilsson, 2002; Malmbjer, 2012; Westman, 2009) visar att skrivande sällan kopplas till ett sammanhang utanför själva skrivandet, vilket kan medföra att elever inte alltid vet varför de skriver (af Geijerstam, 2006; Malmbjer, 2012) och att skrivandet blir av instrumentell karaktär (Malmbjer, 2012). Vikten av att literacyhändelser kopplas till varandra och används i ett meningsfullt sammanhang ser vi därför som en central slutsats i studien.

Att ett meningsfullt sammanhang är viktigt för elevers skrivande är inte något nytt (se till exempel Hidi \& Boscolo, 2006, 2007; Liberg \& Säljö, 2020). Den här studien bidrar dock inte endast med att påtala vikten av detta, utan visar också vad eleverna, enligt deras berättelser, använder skrivande till och vad ett meningsfullt sammanhang innebär för dem. Det handlar om de positioner som eleverna tillskriver sig själva (som en unik elev, som en elev som klarar de krav som ställs) och sina klasskamrater (som elever som ska lära sig något, som elever som ska övertygas) och som möjliggörs genom kombinationen av literacyhändelser. De positioneringar som det sociala samspelet möjliggör kan ses som den här studiens viktigaste kunskapsbidrag.

För att elever ska uppleva skrivande som en meningsfull aktivitet framstår det i studien som viktigt att eleverna ges ett visst agentskap (jfr Bandura, 2001) och ett visst handlingsutrymme. Detta framgår bland annat när eleverna talar om val av ämne och strategier av olika slag. Valet av ämne framstår som särskilt viktigt i två berättelser. Det handlar i dessa berättelser om att välja ett ämne som klasskamraterna inte kan något om (för att bli unik) eller ett nytt och intressant ämne (för att klasskamraterna ska lära sig något). Valet av ämne framstår vara av betydelse för det eleverna vill uppnå och för den funktion eleverna riktar sitt skrivande mot. Ett intresse för ämnet framstår därmed ha åtminstone en viss betydelse för meningsfullt skrivande (Hidi \& Boscolo, 2006, 2007; Renniger et al., 2002). Vad gäller strategier av olika slag 


\section{Fansson, A. Thorsten $\mathcal{E} H$. Löfgren}

framstår de som viktiga i samtliga berättelser. Strategierna används för att anpassa texten till mottagarna och handlar om att kontrollera textens innehåll (till exempel genom att försöka tänka så som mottagarna kan tänkas tänka) och form (till exempel genom att testa texten på en kamrat) (jfr Zimmerman \& Kitsantas, 1999). Tillgång till strategier av detta slag framstår i elevernas berättelser som nödvändigt för det eleverna vill åstadkomma, men inte som något som gör skrivande meningsfullt per se.

Vad gäller elevers självtillit avviker det empiriska materialet i den här studien något från tidigare forskning. Flera studier (Bruning et al., 2013; DeBrine Mascle, 2013) visar att elever med hög självtillit engagerar sig mer i sitt skrivande än andra. I den här studien framgår inte denna skillnad tydligt. De elever som i den här studien förefaller ha en låg självtillit tycks engagera sig i lika hög utsträckning som andra. En möjlig orsak till detta kan vara att eleverna ska redovisa sina texter för klassen. De kan inte undvika att skriva, eller skriva så lite som möjligt, eftersom de då riskerar att misslyckas.

\section{Implikationer}

De elever som deltar i den här studien vet vad som gör skrivande meningsfullt för dem. De svarar på våra frågor, de berättar vad de vill åstadkomma och de beskriver hur de gör för att nå dit. Vad elevernas lärare har för syfte med de skrivuppgifter som eleverna berättar om framgår inte, men det är möjligt att läraren har ett annat syfte än eleverna (jfr Nilsson, 2002). Skolans literacypraktik kan på så sätt betraktas som genomsyrad av en mängd olika syften från olika aktörer, men för att elever ska uppleva skrivande som meningsfullt för dem framstår deras aktörskap som helt avgörande. Det framstår med andra ord som viktigt att eleverna betraktas som medskapare i utformning av skrivuppgifter.

Det sociala (sam)spel som utvecklas mellan eleverna under redovisningen, och som kombinationen av literacyhändelser leder till, framstår enligt elevernas berättelser leda till att deras motivation för skrivande ökar. De spänner bågen och strävar efter att skriva bra texter som fyller den funktion som de tänkt sig. Det sociala samspelet verkar dock inte endast vara kopplat till möjligheter utan också till risker. Riskerna handlar i det här fallet om att inte klara klasskamraters granskning och framstå som misslyckad. För att elevers självtillit vad gäller skrivande inte ska sjunka framstår det därför som viktigt för lärare att balansera mellan möjligheter och risker med redovisning. Med utgångspunkt från Zimmermans och Kitsantas (1999) studie skulle undervisning som ger elever tillgång till fler strategier för skrivande kunna vara ett förslag. Det handlar om att hantera det sociala spel som utvecklas mellan elever och som kan medföra såväl vinnare som förlorare.

\section{Författarbiografi}

Magnus Jansson är adjunkt och doktorand vid institutionen för beteendevetenskap och lärande, Linköpings universitet. Magnus doktorsavhandling handlar om skrivande på mellanstadiet. 
Anja Thorsten är lektor vid institutionen för beteendevetenskap och lärande, Linköpings universitet. Anjas forskningsintresse riktas mot elevers skrivande och didaktiskt ledarskap.

Håkan Löfgren är biträdande professor vid institutionen Tema, Linköpings universitet. Håkans forskningsintresse riktas främst mot lärares professionalism, bedömning och betygssättning.

\section{Referenser}

Bamberg, M. G. W. (1997). Positioning between structure and performance. Fournal of Narrative and Life History, 7(1-4), 335-342.

Bandura, A. (1997). Self-efficacy: The exercise of control. Freeman.

Bandura, A. (2001). Social cognitive theory: An agentic perspective. Annual Review of Psychology, 52, 1-26. https://doi.org/10.1146/annurev.psych.52.1.1

Barton, D. (2007). Literacy: An introduction to the ecology of written language. Blackwell Publishing.

Boscolo, P. \& Carotti, L. (2003). Does writing contribute to improving high school students' approach to literature? L1 - Educational Studies in Language and Literature, 3, 197-224.

Britton, J., Burgess, T., Martin, N., McLeod, A. \& Rosen, H. (1975). The development of writing abilities. Macmillan.

Bruning, R., Dempsey, M. \& Kauffman, D. F. (2013). Examining dimensions of self-efficacy for writing. Fournal of Educational Psychology, 105(1), 25-38. https://doi.org/10.1037/a0029692

Bryman, A. (2018). Samhällsvetenskapliga metoder (3 upp.). Liber.

DeBrine Mascle, D. (2013). Writing self-efficacy and written communication skills. Business and Professional Communication Quarterly, 76(2), 216-225. https://doi.org/10.1177/1080569913480234

af Geijerstam, ̊. (2006). Att skriva $i$ naturorienterande ämnen $i$ skolan. Acta Universitatis Upsaliensis.

Goodson, I. F. \& Sikes, P. J. (2001). Life history research in educational settings: Learning from lives. Open University Press.

Graham, S., Berninger, V. \& Fan, W. (2007). The structural relationship between writing attitude and writing achievement in first and third grade students. Contemporary Educational Psychology, 32(3), 516-536. https:// doi.org/10.1016/j.cedpsych.2007.01.002

Graham, S. \& Harris, K. R. (2000). The role of self-regulation and transcription skills in writing and writing development. Educational Psychologist, 35(1), 3-12. https://doi.org/10.1207/S15326985EP3501_2

Hall, K. (2013). Effective literacy teaching in the early years of school: A review of evidence. I J. Latson \& K. Marsch (Red.), The Sage handbook of early childhood literacy (s. 315-327). Sage Publications.

Heath, S. B. (1983). Ways with words: Language, life, and work in communities and classrooms. Cambridge University Press.

Hidi, S., Berndorff, D. \& Ainley, M. (2002). Children's argument writing, interest and self-efficacy: An intervention study. Learning and Instruction, 12(4), 429-446. https://doi.org/10.1016/S0959-4752(01)00009-3

Hidi, S. \& Boscolo, P. (2006). Motivation and writing. I C. A. MacArthur, S. Graham \& J. Fitzgerald (Red.), Handbook of writing research (s. 144-157). Guilford Press.

Hidi, S. \& Boscolo, P. (2007). The multiple meanings of motivation to write. I S. Hidi \& P. Boscolo (Red.), Writing and motivation (s. 1-14). Elsevier.

Kohler Riessman, C. (2008). Narrative methods for the human sciences. Sage.

Langer, J. A. (2004). Getting to excellent: How to create better schools. Teachers College Press.

Liberg, C. \& Säljö, R. (2020). Grundläggande färdigheter - att bli medborgare. I U. P. Lundgren, R. Säljö \& C. Liberg (Red.), Lärande, skola, bildning (s. 403-424). Natur \& Kultur.

Lipstein, R. \& Renniger, K. A. (2007). "Putting things into words": 12-15 year-old students' interest for writing. I S. Hidi \& P. Boscolo (Red.), Motivation and writing: Research and school practice. Elsevier.

Magnusson, J. (2018). Det diskursiva skrivandets funktion - en läromedelsanalys. Nordic fournal of Literacy research, 4(1). https://doi.org/10.23865/njlr.v4.960

Malmbjer, A. (2012). Elevers skriftbruk i och utanför skolan. I A. Skaftun \& S. Matre (Red.), Skriv! Les!, Artikler fra den første nordiske konferensen om skriving, lesing og literacy, 2012 (s. 15-28). Akademika Forlag. 


\section{Fansson, A. Thorsten \& H. Löfgren}

Mishler, E. G. (1999). Storylines: Craftartists' narratives of identity. Harvard University Press.

Nilsson, N.-E. (2002). Skriv med egna ord: En studie av läroprocesser när elever $i$ grundskolans senare år skriver "forskningsrapporter". Lund University Publications.

Pérez Prieto, H. (2006). Historien om räven och andra berättelser: Om klasskamrater och skolan på en liten ort - ur ett skol- och livsberättelse perspektiv. Karlstad University Studies.

Renniger, K. A., Ewen, L. \& Lasher, A. K. (2002). Individual interest as context in expository text and mathematical word problems. Learning and Instruction, 12(4), 467-491. https://doi.org/10.1016/S09594752(01)00012-3

Scribner, S. \& Cole, M. (1981). The psychology of literacy. Harvard University Press.

Skolverket. (2019). Läroplan för grundskolan, förskoleklassen och fritidshemmet 2011 (reviderad 2019). Fritzes.

Smidt, J. (2007). Hva skriving brukes til: Ett års skriving på 4. trinn. I S. Matre \& T. L. Hoel (Red.), Skriving for nåtid og framtid (s. 234-248). Tapir.

Smidt, J. (2011). Finding voices in a changing world: Standard language education as a site for developing critical literacies. Scandinavian fournal of Educational Research, 55(6), 655-669. https://doi.org/10.1080/ 00313831.2011 .594608

Solheim, R., Larsen, A. S. \& Torvatn, A. C. (2010). Skrivekulturar på mellomtrinnet - tre døme. I J. Smidt (Red.), Skriving $i$ alle fag - innsyn og utspill (s. 39-65). Tapir.

Street, B. V. (1984). Literacy in theory and practice. Cambridge University Press.

Troia, G. A., Shankland, R. K. \& Wolbers, K. A. (2012). Motivation research in writing: Theoretical and empirical considerations. Reading and Writing Quarterly, 28(1), 5-28. https://doi.org/10.1080/10573569. 2012.632729

Vetenskapsrådet. (2011). God forskningssed. Vetenskapsrådet.

Westman, M. (2009). Skriftpraktiker i gymnasieskolan: Bygg- och omvårdnadselever skriver. Acta Universitatis Stockholmiensis.

Westman, M. (2013). Fyll i och skriv på!: Analys av skrivuppgifter i läromedel i svenska för årskurs 4. I D. Skjelbred \& A. Veum (Red.), Literacy i lceringskontekster (s. 201-211). Cappelen Damm AS.

Zimmerman, B. J. \& Kitsantas, A. (1999). Aquiring writing revision skill: Shifting from process to outcome self-regulatory goals. Fournal of Educational Psychology, 91(2), 241-250. https://doi.org/10.1037/00220663.91.2.241

Zimmerman, B. J. \& Kitsantas, A. (2002). Aquiring writing revision proficiency through observation and emulation. Fournal of Educational Psychology, 94(4), 660-668. https://doi.org/10.1037/0022-0663.94.4.660 